\title{
HEALTH SYSTEM REFORMS IN MATURE WELFARE STATES: TALES FROM THE NORTH
}

\section{Reforma dos sistemas de saúde em estados de bem-estar social amadurecidos: contos do Norte}

\section{Reformas de los sistemas de salud en los estados maduros de bienestar: historias del Norte}

\author{
Jean-Louis Denis \\ Université de Montréal - Montréal - Canada
}

\section{Susan Usher}

École nationale d'administration publique - Montreál - Canada

\author{
Johanne Preval \\ Centre hospitalier de l'Université de Montréal - Montréal - Canada
}

\section{Élizabeth Côté-Boileau}

Université de Sherbrooke - Québec - Canada

\begin{abstract}
Objective: This article has the objective show an essay on emerging themes in health system reforms, based on experience in Canada. Data synthesis: Reforms are the privileged mode of social change used by modern democratic societies. Persistent dysfunction and failure to adapt to emerging health needs and priorities within health systems in Canada provide a strong policy rationale to search for alternative strategies that might produce much-needed reforms. Three persistent challenges and opportunities for reform in Canadian health systems are discussed: the design of effective governance arrangements, the largescale development and implementation of improvement and transformative capacities, and the leadership and engagement of the medical profession in working toward broad system goals. In exploring these challenges, we identify tensions that seem relevant to better understanding health system reform in mature welfare states. Conclusion: Addressing these tensions will require both a reinforcement of state and government capacities and stronger capacities at all levels of the health system to design and support change.
\end{abstract}

Descriptors: Health Systems; Health Care Reform; Health Planning.

\section{RESUMO}

Objetivo: Este artigo tem como objetivo apresentar um ensaio sobre temas emergentes em reformas de sistema de saúde, com base na experiência do Canadá. Síntese dos dados: Reformas são o modo privilegiado de mudança social usado pelas sociedades democráticas modernas. Disfunção persistente e deficiência na adaptação às emergentes necessidades de saúde e prioridades dentro dos sistemas de saúde no Canadá propiciam uma forte argumentação política para a busca de estratégias alternativas que possam produzir as tão necessárias reformas. Três desafios persistentes e oportunidades para reforma nos sistemas de saúde canadenses são discutidos: o delineamento de arranjos de gestão efetivos, o desenvolvimento e a implementação em larga escala de capacidades de melhoria e transformação, e a liderança e engajamento da classe médica no trabalho em direção aos amplos objetivos do sistema. Ao explorar esses desafios, identificamos tensões que parecem relevantes para melhor se compreender a reforma do sistema de saúde em estados de bem-estar maduros. Conclusão: O enfrentamento dessas tensões exigirá tanto um reforço das capacidades do Estado e governamentais como capacidades fortalecidas em todos os níveis do sistema de saúde para projetar e apoiar a mudança.

Descritores: Sistemas de Saúde; Reforma dos Serviços de Saúde; Planejamento em Saúde.

Este artigo foi selecionado, corrigido e aprovado pela Comissão Científica do Fórum Internacional de Sistemas Universais de Saúde, seguindo suas normas e formatação. 


\section{RESUMEN}

Objetivo: Ese artículo tiene el objetivo de mostrar un ensayo de temas emergentes de las reformas del sistema de salud basados en la experiencia de Canadá. Síntesis de los datos: Las reformas son un modo privilegiado de cambio social utilizado por las sociedades democráticas modernas. La disfunción persistente y el fracaso para adaptar las necesidades y prioridades de salud dentro de los sistemas de salud de Canadá aportan una política racional fuerte para buscar estrategias alternativas que puedan producir las reformas necesarias. Tres desafíos persistentes y oportunidades para la reforma en los sistemas de salud de Canadá son discutidos: el diseño de acuerdos de gobierno efectivos, el desarrollo e implementación en larga escala de mejoría y capacidades transformativas y el liderazgo y compromiso de la profesión médica en trabajar hacia los objetivos de sistema amplio. Explorando estos desafíos hemos identificado tensiones que parecen relevantes para una mejor comprensión de la reforma del sistema de salud en los estados maduros de bienestar. Conclusión: Direccionar estos desafíos necesitará un refuerzo de las habilidades del estado y del gobierno y habilidades más fuertes en todos los niveles del sistema de salud para diseñar y apoyar el cambio.

Descriptores: Sistemas de Salud; Reforma de la Atención de Salud; Planificación en Salud.

\section{INTRODUCTION}

Canada is a decentralized federal state, where responsibility for planning, delivering and funding the health system falls primarily to provincial and territorial jurisdictions. In this paper, we explore health reforms undertaken since the mid-1990s in various provinces to reveal challenges and opportunities faced by so-called public healthcare systems in mature welfare states. A noted Canadian political scientist and commentator on health system reform perceived, in her comparative analysis of health systems in high-income countries, a move away from ideal types (Beveridgian, Bismarkian) toward more hybrid systems that enable political and institutional entrepreneurs to play a greater role in driving change and innovation.

The mature health systems were created in the golden age of the welfare state and now have to adjust to a new set of pressures and contingencies. In addition, she suggested that Canada has greater difficulty bringing about significant changes or reforms than countries such as the United Kingdom (UK) and The Netherlands, due to factors such as the bilateral monopoly over health policies held by government and the medical profession.

In a book published in 2013 , another group of political scientists and health policy analysts concluded that Canadian jurisdictions were unable to implement significant health reforms due to a particular configuration of political institutions, pressures and resistance. Together, these factors were seen to create a form of endemic inertia they labelled Paradigm Freeze ${ }^{(1)}$. In this paper, we explore the content and dynamics of reforms in the health systems of a number of Canadian provinces to better understand the interplay between change and inertia that seems to characterize their trajectory.

This article has the objective to show an essay on emerging themes in health system reforms, based on experience in Canada.

\section{DATA SYNTHESIS}

\section{Context and experience of reforms}

Canada is a high-income country according to criteria used by the World Bank. In terms of health spending, Canada ranked $7^{\text {th }}$ among selected Organization for Economic Co-operation and Development (OECD) countries in 2015 , with total spending on health equal to $10.4 \%$ of Gross Domestic Produtive (GDP), or $\$ 5,782$ per capita. The public-sector share of total spending is $70.4 \%$, which is somewhat lower than the OECD average ${ }^{(2)}$. The population of Canada is now at 36.7 million, distributed unevenly between provinces, from just 152,000 in tiny Prince Edward Island, to 14.1 million in Ontario, the country's largest province ${ }^{(2)}$.

Reforms are the privileged mode of social change used by modern democratic societies ${ }^{(3)}$. In the context of this paper, reform is defined as deliberate changes to the structures and processes of public sector organizations with the objective of getting them (in some sense) to run better ${ }^{(4)}$.

Whether or not the benefits anticipated from reform are achieved is highly dependent on how policy ambitions are supported and implemented by government, public organizations and non-state actors. Health care is characterized by complex social and political dynamics that make government intervention more or less possible or legitimate ${ }^{(5)}$. In 
addition, reforms are not the sole purview of policy-makers ${ }^{(6,7)}$ they also emerge from a dispersed set of policy actors that structure a market of ideas, where broad doctrines and techniques are promoted in a more or less coherent way ${ }^{(4)}$.

Reforms of healthcare systems are on the political agenda in all OECD countries and include a wide range of policies aiming to improve healthcare delivery systems, optimize the use of resources and advance population health. The scope of these policies varies according to the institutional tradition of each country, their transformative capacities and the specific challenges they must address. Canada is no exception, undertaking multiple reorganizations and reforms, conditioned by predominant political ideologies, to respond to pressing contingencies. As with other countries, controlling costs is a major preoccupation. In Canada, growth in healthcare spending has slowed after reaching a peak of $11.6 \%$ of GDP in 2010, decreasing by an average $0.2 \%$ per year between 2010 and $2014^{(8)}$.

While cost control is an important objective, it is not synonymous with delivering effective and appropriate care ${ }^{(0,10)}$. Reports and analyses in the last 15 years suggest that substantive change remains elusive in Canada ${ }^{(10-15)}$.

A recent report commissioned by Health Canada ${ }^{(16)}$ suggests the need to renew the Canada Health Act of 1984, which provides the federal framework for healthcare policy across the country, in order to promote national programs to support a data-driven health system and meet needs for home care, mental health care and affordable drugs. The viability of this federal policy agenda will rest on the political will of the provinces and territories, and on their ability to cover the cost of new programs or expansions to public coverage in existing programs. While Canada's jurisdictional structure presents particular challenges, some international observers argue that it will be very difficult to significantly transform public healthcare systems generally ${ }^{(17,18)}$, suggesting that Canada's challenges are not exceptional.

Persistent dysfunction and failure to adapt to emerging health needs and priorities ${ }^{(10)}$ within health systems in Canada provide a strong policy rationale to search for alternative strategies that might produce much-needed reforms. A recent book on the experience of health reforms in Ontario finds that health systems struggle to achieve systemness but have never fully succeeded the trajectory of system building continues to be distressingly flat. In addition to the political challenge of change, many key policy issues have yet to be discussed, much less settled, by the governments that must take responsibility for governing our healthcare system ${ }^{(19)}$.

Policy uncertainties in Canadian healthcare systems ${ }^{(12)}$ are stimulating a new wave of reform initiatives in various provinces, offering a unique opportunity to learn from different attempts to transcend the paradigm freeze. In this paper, we explore these reforms in order to better understand the challenges in bringing about change and the opportunities that appear promising in recent efforts.

\section{Persistent challenges and opportunities for reform in Canadian health systems Governance for health system performance and population health}

Governance has been an enduring theme in the Canadian health policy landscape. Governance involves balancing the multiple conflicting logics and interests of patients, staff, citizens, and politicians as well as other stakeholders ${ }^{(20)}$ while focusing on improving access, quality and outcomes, and has different scope and focus at micro, meso and macro levels ${ }^{(21,22)}$.

During the 1990s, nine of the 10 Canadian provinces created some sort of regional governance bodies, called Regional Health Authorities (RHAs) ${ }^{(23)}$. The assumption was that RHAs would increase capacities to adapt health systems to regional realities and better respond to population needs. RHAs were expected to effectively mediate between central government policies and local priorities: Canada's geography creates significant differences between healthcare priorities in urban, rural and remote areas, concerns that informed the creation of RHAs as governance bodies.

In most provinces, the creation of RHAs in the 1990s was accompanied by the dissolution of the local governing boards of healthcare delivery organizations and was likely seen by local communities as an increased centralization. For central (provincial) governments, it spelled decentralization to an intermediate level of governance within the health system. The impact of this movement toward regional structures is the subject of much debate ${ }^{(24,25)}$ and the question remains unsettled.

Some authors ${ }^{(26)}$ have argued that RHAs often played the role of buffer between the austerity policies of provincial governments and the local delivery of health and social care. In periods of severe budgetary cutbacks, RHAs may have helped to limit the damage by undertaking reorganizations that were somewhat coherent with local realities. In Canada, RHAs appeared as new players within the governing apparatus and were ultimately an instrument of provincial government. The recent history of health reforms in Canadian health systems supports this interpretation, as it has underlined the fragility of RHAs as a governing structure. 
In the early 2000s, a number of provinces reduced the number of RHAs and, in 2008, the province of Alberta became the first to move away from regional governance altogether, abolishing its nine RHAs and creating Alberta Health Services as a single governing board for its health system. The consolidation was justified by arguments that it would increase efficiency, enable linkages across various resources in the system (notion of systemness) and facilitate a more managerial and less politicized approach to running the system. Alberta Health Services (AHS) is responsible to the Ministry of Health for delivering health services to the province's population, but is, in principle, less susceptible to political interference. The ambition of de-politicization in the governance of health systems somewhat reflects the penetration of New Public Management (NPM) ideas ${ }^{(27)}$ suspicious of the expansion of the bureaucratic apparatus of the state and concerned about redundancy. Reducing the number of levels of governance within health systems satisfied a perceived need to control the expansion of public bureaucracies and for politicians to increase their sense of control over the health system.

It is difficult, at this stage, to clearly assess the benefits of centralization and consolidation of governance structures in Canada's health systems. For example, the creation of Strategic Clinical Networks (SCNs) under AHS in Alberta has increased the coordination and appropriateness of care in some key clinical areas and is considered a very positive experience ${ }^{(28)}$.

\section{Clinical governance as a lever to improve health systems}

While governments in Canadian provinces have privileged reorganization and restructuring as a form of intervention in health systems, we see a growing trend toward diversifying the levers and instruments for transformation and improvement. In this section, we will discuss one of these levers, clinical governance that appears to be gaining ground in the reform efforts of a number of provinces. Clinical governance involves processes that connect clinical practice more explicitly to the organizational context and are aimed, on one hand, at fostering the creation of an organizational environment that develops professional practices and, on the other, at operating directly on professional practices to ensure better quality of care ${ }^{(29)}$.

Clinical governance is based on the assumption that there are, in any health setting, latent capacities that can be harnessed to generate improvements. By focusing efforts on the level of clinical settings, health system reformers can access resources and processes for improvement that are not available through interventions restricted to meso or macro system levels ${ }^{(22)}$. These approaches are rooted in work on clinical microsystems ${ }^{(30)}$, high-performing clinical units $^{(31,32)}$, high-performing health systems ${ }^{(33)}$, and collaborative quality improvement in health care ${ }^{(34-36)}$.

For example, the Canadian Foundation for Healthcare Improvement (CFHI) partnered with organizations in a number of provinces to experiment with collaborative improvements. These initiatives could be confined to local settings, or developed as province-wide initiatives, such as projects aimed at reducing the use of antipsychotics in people with dementia in long-term-care settings ${ }^{(37)}$.

Another example is the growing interest in the development of strategic clinical networks (SCNs) and health quality councils across Canada. Alberta Health Services has promoted the development of SCNs in various sectors of care since 2012. SCNs are the mechanism which AHS is using to empower and support physician and clinical leaders in both AHS and the community to develop and implement evidence-informed, clinician-led, team-delivered health improvement strategies across Alberta. SCNs will also focus on leading and supporting evidence-informed improvements in team-delivered prevention and in clinical performance to achieve the highest quality and best outcomes at the lowest reasonable costs ${ }^{(38)}$.

To date, the province has created $15 \mathrm{SCNs}$ in areas ranging from cardiovascular disease and stroke, to public and indigenous health, with two further SCNs expected in 2018. Cumulative effects show cost savings along with better access and/or quality of care. For example, improved practice in the Bone and Joint has ensured that people are mobilized quickly following hip and knee surgery, allowing them to return home sooner and prevent readmissions; the effort has freed up over 50,000 hospital bed days since $2009^{(39)}$.

Another trend apparent since the turn of the millennium involves the creation of health quality councils in five of the 10 Canadian provinces, namely British Columbia, Alberta, Saskatchewan, Ontario and New Brunswick ${ }^{(16)}$. These agencies, which operate at arms' length from provincial government, aim to support health providers and organizations in achieving better care and higher performance. Quality councils are expected to contribute expertise and tools to healthcare delivery organizations and front-line providers to help them adapt to new demands and increase their capacity for improvement. The development of quality standards is often accompanied by training programs in improvement methodologies and coaching of clinicians in different care settings. In Saskatchewan, the 
Health Quality Council played a lead role in introducing approaches such as The Productive Ward - Releasing Time to Care, and in training the healthcare workforce in Lean improvement methodology ${ }^{(40)}$.

While it is difficult to assess these agencies contribution to health system improvement, they reveal a growing preoccupation with creating a facilitative context for improvement rather than relying on more coercive approaches ${ }^{(41)}$. In addition, as observed in many health systems in high-income countries ${ }^{(42)}$, we see in Canadian provinces an expansion of health networks such as SCNs to compensate for the limited ability of central governance structures to achieve coordination in the health system.

\section{The medical profession and prospects for innovation in health policies}

The question of physician engagement, leadership and accountability is an enduring issue in health policy and reforms ${ }^{(31,43-45)}$. Medical doctors play a crucial role in determining the allocation and utilization of resources in health systems, and in shaping capacities to renew policy orientations and models of care. The status of the medical profession and the bilateral monopoly between state and the profession have been underlined as a major cause of blockages in health reforms in Canada ${ }^{(1)}$.

The theme of medical leadership and engagement surfaces in various forms and through a variety of initiatives across provincial health systems in Canada and at national level. For examples, the Canadian Medical Association has, since 1999, offered physicians a training program in leadership ${ }^{(46)}$. The province of British Columbia has developed a Facility Engagement Initiative to support physician participation in hospital improvement efforts, along with a Physician Quality Improvement Initiative to support physicians in leading quality improvement projects ${ }^{(47)}$.

In addition, there have been major efforts in the last 15 years to restructure primary care and more specifically to develop the role of general practitioners in the health systems of various provinces ${ }^{(48)}$. Important investments have been made in Ontario and Quebec to create and support primary care groups, with the objective of increasing access to family physicians. While these initiatives have provided positive results on access to family physicians for the general population, the cost of these projects and their still uncertain impact on access to care and continuity of care, specifically for the more vulnerable segments of the population, remains an issue ${ }^{(49)}$.

In Manitoba, the Physician Integrated Networks initiative focuses on fee-for-service (FFS) physician groups to facilitate systemic improvements in the delivery of primary care: all participating clinics receive funding based on quality performance targets ${ }^{(50)}$. Quality-based improvement funding (QBIF) was introduced in Manitoba as an opportunity to experiment with a blended model of physician compensation, mixing pay-for-performance with fee-for-service ${ }^{(51)}$.

Our objective here is not to provide an exhaustive list of initiatives that support an expanded role for the medical profession in transforming and improving health systems in Canada. Suffice it to say that an important part of the healthcare budget in Canada ( $15.4 \%$ as a national average) goes to services provided by general practitioners and specialists. Payments to physicians grew at an annual rate of $6.2 \%$ over the decade to 2014 , with growth slowing to just over $3 \%$ each year since then ${ }^{(8)}$ and governments are still struggling to find ways of getting the best out of these resources. In the years to come, this issue will continue to present a major challenge to health reformers in Canada. Despite the fact that they are paid with public money, the status of medical doctors as independent entrepreneurs may limit the ability to fully recognize that medicine is, in the end, a public service profession ${ }^{(52)}$.

The medical profession in Canada also exerts significant influence on what other health professionals can do in the health system. Rules around scope of practice and funding for education and positions within the health system are important levers for change. Significant variations between provinces in the use of nurse practitioners provide an indication of government finesse in negotiating with physician interests that might fear a potential loss of terrain. In 2016, $57.3 \%$ of all NPs in Canada were working in Ontario $(n=2,769)$, while only $7.9 \%$ were in place in Québec $(\mathrm{n}=380)^{(53)}$.

Variations are also seen in the scope of practice allowed for other healthcare professionals: while most provinces now allow pharmacists to switch or adjust dosages independently, only a few allow them to initiate a prescription under delegation ${ }^{(54)}$. Several provinces are experimenting with advanced paramedics to provide care for rural residents with chronic conditions. Physician assistants, who have an important place in comparable health systems such as the UK, were endorsed by the Canadian Medical Association in 2003, but are still not commonly integrated into the health system: only four provinces now have physician assistants in practice, and only two provinces offer training programs $^{(55)}$.

\section{Exploring the politics of health system redesign in mature welfare states}

In the section above, we identify three policy challenges that emerge from attempts to reform health systems in Canadian provinces. These involve the design of effective governance arrangements, the large-scale development 
and implementation of improvement and transformative capacities, and the leadership and engagement of the medical profession in working toward broad system goals. In this next section, we will explore a set of tensions that seems relevant to better understanding the challenges of health system reform in Canada. As in our discussion of the policy challenges above, the tensions we highlight are not meant to be exhaustive, but rather illustrate and help to interpret some of the key issues at the heart of reform dynamics.

\section{The tension between centralized and decentralized approaches to governance in health systems}

Authors $^{(20)}$ argue in favour of a health system governance approach that departs from the traditional commandand-control model, which, in generic terms, resembles traditional public administration governance where control over the system and policy capacities is located within central government. Reformers from various ideological and theoretical standpoints have challenged centralized models of governance. Ideas about NPM have infiltrated discourse and practice in public management in many jurisdictions ${ }^{(56,57)}$.

In Canada, concerns about cost control and the size of government and the public service have prompted calls for stronger managerial capacities to improve efficiency. Such demands have often been framed in very conservative political terms, and confound the need for managers to gain in adaptability with a drive to limit state and government involvement in health care and others sectors ${ }^{(58,59)}$. From a conservative standpoint, the fundamental assumption here is that government necessarily fails to provide efficient and effective services ${ }^{(6)}$ because of its tendency to grow and overspend in the absence of competition ${ }^{(61)}$.

Scholars interested in reinventing government ${ }^{(62)}$ suggest that a significant renewal of policy instruments based on the private sector, such as contracting out and public-private partnerships, will help renew the health system. While critics of the NPM approach have been very vocal, there is a social demand to increase the capacity of public healthcare systems to respond to challenges of an aging population and the anticipated costs of new sophisticated health interventions (genomics, precision medicine, technological innovations such as sophisticated surgical robots).

An alternative approach to NPM in countering command-and-control-style governance involves decentralization through network governance or policy networks ${ }^{(56,57,63)}$. This trend is based on a more progressive political ideology and promotes elements of Third Way political thinking that became fashionable in the early 2000s. From this perspective, the centralization and consolidation of governance authority observed in recent health reforms in many Canadian provinces are in tension with network governance that emphasizes the notion of distributed capacities in health policy-making. A network approach to governance recognizes central government's diminished capacity to design and drive policies that are crucial to health system evolution: government no longer has a monopoly on the knowledge and competencies required to push adaptation. According to this model, organizations and actors within society are interdependent, and no one body can pretend to have all the resources (cognitive, political, operational, etc.) needed to solve key policy challenges.

Policy capacity thus requires contributions from non-traditional policy actors ${ }^{(64)}$. In a network perspective, polycentric governance becomes the norm, and the challenge is to effectively articulate the roles and responsibilities of these various entities and organizations in reforms ${ }^{(65)}$.

Both NPM and network governance models challenge the relevance of developing centralized authority to govern health systems. However, more centralized forms of governance may present opportunities for greater policy coherence. For example, broad policy goals such as improving population health are probably consistent with a more centralized approach that ensures equity in resources allocation and transfers some resources from the medical complex to population health interventions ${ }^{(66)}$. A centralized approach may also increase capacity to spread and scale up innovations, invest in capacity development, and use strategic intermediary agencies such as health quality councils.

There is no definitive solution to the dilemmas of adopting more concentrated or more distributed approaches to governance, and this may explain the long-standing interest in public administration and political science for the balance between centralization and decentralization in policy making. One might argue that a strong central government, committed to supporting the public healthcare system, will be in a better position to support policies that aim for greater redistribution towards those with greater needs. However, the benefit of centralized forms of authority probably has to be balanced with strong policy and operational capacities at other levels of the health system. In addition, the complexity of contemporary social and policy issues means that models of collaborative governance(67) may appear more effective. In the end, the challenge for reformers is to reconcile strong policy capacities of central governments and states with a more open and collaborative approach to governing health systems. This dilemma 
is also related to another tension evident in Canadian health systems around the reconciliation of micro and macro governance dynamics.

\section{The tension between micro and macro scale in health system change and improvement}

A former Minister of Health described the Canadian health system as a land of pilot projects. There are many pockets of excellence and innovative experiments, but persistent challenges in achieving large-scale change. On the one hand, the challenge involves learning from local experience and understanding the implications of developing these innovations or improvement efforts into system-wide changes ${ }^{(68)}$.

On the other hand, the challenge is to mobilize the authority of central governments to stimulate the adoption, implementation and spread of innovative policies and delivery strategies across the health system. It is important to remember that these innovative policies aim to change the way health resources are distributed and used. For example, recent emphasis on providing care in the community and enhancing primary care has been accompanied by a significant reduction in the growth in hospital spending in Canada. Where hospitals represented around $40 \%$ of total health expenditure in 1990, in 2017 they accounted for $28 \%$. Physicians remain quite stable at around $15 \%$, with a slight rise evident since 2005 , and drug expenditures account for an ever-larger share, rising from about $10 \%$ of total health expenditures in 1990 to $16.4 \%$ in $2017^{(2)}$.

On the other hand, we see that, despite the increasing attention to mental health as a priority, provincial spending on mental health as a proportion of total public health expenditures actually dropped between 2003 and 2013, from $5.4 \%$ to $4.9 \%$, with significant variations between provinces ${ }^{(69)}$. The shortfall in home care is equally important: a recent national action plan for home care advocated by national associations of nurses and physicians considered that home health care and support services should account for $10 \%$ of total public health expenditures; in 2013, it was only $4 \%^{(70)}$.

A major obstacle to innovation and reform appears in the difficulties central governments (both federal and provincial) face in allocating sufficient resources to priority sectors such as primary care, home care and mental health care. This persistent challenge has prompted increasing calls to renew the Canada Health Act in order to expand public coverage to areas beyond medically necessary care provided by physicians or in hospitals ${ }^{(16)}$.

This is symptomatic of growing recognition of the political substrate of large-scale system change. After 25 years of provincial and pan-Canadian experiments, the current call for broader systemic change recognizes that significant improvement requires more than the dissemination and scale-up of local innovations. However, producing and sustaining large-scale change demands a balance between policy determination and clarity, and the ability to adapt and execute these policies at all levels of the system ${ }^{(71)}$.

Based on the three policy challenges described above, policy work to rebalance the health system appears unavoidable, and demands that we look at the health system as a political-economic machine that is largely drive by patterns of interest ${ }^{(72)}$ and by path dependency ${ }^{(73)}$. The center of gravity of Canadian health systems around medical and hospital services, coupled with vested interests, institutional sedimentation and growing population expectations for access to innovative health technologies make real reforms difficult to achieve.

\section{The tension between innovation and regulation}

There is a wide consensus that health systems and organizations in Canada demonstrate a limited ability to adapt, innovate and improve at a sufficient pace ${ }^{(74-78)}$. This leads to a particular tension for healthcare communities who invest a lot of energy in attempting to increase the impact of innovation within and beyond jurisdictions. In the previous section, we focused on political obstacles to reform. In this section, we look at how policy capacities at the central level can support the development of ecologies for innovation ${ }^{(79)}$ at meso and micro system levels. In order to address this issue, we need to renew our perspective on how these levels (macro, meso, micro) interact with each other to defuse the tension between innovation and regulation.

\section{The unpredictable adaptation journey of innovation}

It is hardly new to suggest that the innovation journey is unpredictable, as many scholars have already explored this phenomenon ${ }^{(80-84)}$. However, what remains less explored is the dialectical relationship between how the substance of innovation adapts to regulations set at the central (macro) level, and vice versa, and how these adaptations trickle down through the system (to meso and micro levels). To shed the light on this issue, we will look at the competing forces that surround innovation in health policy dynamics. 
In health care, as in others policy sectors, evidence around the substance and the benefits of an innovation competes with other forms of knowledge, such as experiential knowledge, ideologies and values, and more broadly with patterns of interests ${ }^{(8)}$. Many years ago, author ${ }^{(86)}$ considered that innovation was more likely to succeed if it was perceived as: (1) advantageous relative to current practice, (2) compatible with work context, (3) had a manageable level of complexity, and (4) provided opportunities for trial -and error.

Some authors consider that regulations at the policy level may reduce the importance of these conditions for success and accelerate the journey of innovation within the system ${ }^{(87,88)}$. Because of the pluralist and heterogeneous nature of health care, it may be important to maintain a balance between policy-driven innovations and local dynamics of change and innovations ${ }^{(89)}$. The ability to adapt innovation therefore becomes crucial.

Recent literature on the spread and scaling-up of innovations supports the idea that local adaptation allows for fidelity to the innovation through the implementation phase, and fosters its sustainability over time ${ }^{(90-93)}$. In this regard, sociologists of science ${ }^{(94)}$ and organizational theorists ${ }^{(95,96)}$ have emphasized the importance of paying attention to how practices are shaped by context and interactions that influence the ability of a given milieu to adopt an innovation and adapt it to evolving contingencies. According to this work, the ease of adopting an innovation will vary, and strategies to bridge groups and organizations with divergent views appear crucial ${ }^{(97-105)}$.

\section{Agency and innovation in health systems}

While work on innovation highlights the importance of local adaptation and contextualization, analysis of institutions suggest that actors may have difficulty adopting and implementing innovations. Many authors have explored the central question: how is it possible for individuals within an institutional environment that seeks to strengthen continuity and compliance, to innovate and think about new ways of doing things and institutionalize them? ${ }^{(106-108)}$

This question has been referred to as the paradox of embedded agency in institutional analysis ${ }^{(109,110)}$. To overcome this paradox, scholars looking at both industry and public sectors ${ }^{(111,112)}$ have examined attributes of context that favor innovation. Without going into too much detail, this body of work identifies a set of conditions that supports the innovative work of actors in highly institutionalized settings such as health systems. Among these conditions, they underline the opportunity for agents to experiment with alternate practices (such as new models of care), the capacity to monitor and learn from these experiments, mechanisms to support collaboration among interdependent but autonomous actors, and strategies to connect promising local experiments to predominant institutions and regulations in a given sector.

While it may present a somewhat idealistic view of the notion of spaces for innovation, this literature emphasizes the importance of creating environments that are conducive to experimentation. For example, some researchers are now looking at ways to introduce venture capital models into the development and experimentation of new care technologies and models of care aligned with the needs of publicly funded health systems ${ }^{(113)}$.

In addition, training to develop agentic capacities in network management and community mobilization is important. The idea here is that innovation always results to some extent from a process of experimentation, accommodation and normalization. Policies and regulations can be designed to support innovators and institutional entrepreneurs within the health system.

\section{Disruptive innovation and the role of distributed capacities}

Innovation is always at least somewhat disruptive ${ }^{(114-117)}$. Innovations that are minimally disruptive will make their way into the health systems if there is determination to challenge some of the forces of inertia in health care ${ }^{(18)}$. Innovation demands changes to the usual ways of doing things in the daily life of an organization or a system. These efforts have been referred to as innovation work, meaning the emotional and behavioural adjustments that potential users have to make to put an innovation into practice. Innovation work is not an individual task - it is enacted through distributed efforts and governance capacities ${ }^{(118-120)}$.

Adjustments in practices are needed not only at the level of individual adopters ${ }^{(121)}$. The implementation of new models of care, such as community interventions to support people with severe mental health issues, will require governance changes in the roles of professional groups, in the relations among providers from various sectors, in the financing of care, in regulations and labour contracts, and in the politics that shape the delivery of care. Overall, any significant innovation is a source of destabilization and change in both practice settings and the broader policy context ${ }^{(122)}$. Innovation work can be facilitated by supporting distributed capacities within the health system and by policies that promote a better alignment between the characteristics of the innovation and the system's functioning and regulations. 


\section{Discussion and conclusion: The politics of health system redesign}

In her analysis of reforms in mature health systems, one author ${ }^{(123)}$ suggests that we are entering a period of system redesign that contrasts with previous modes of reform: The politics of this redesign phase differ from both the 'high politics' of welfare-state establishment and the stealth politics and short-term budgetary unilateralism of welfare-state retrenchment. In the redesign phase, opportunities for re-allocation and re-investment are seized upon by certain actors within the healthcare system who see the potential to benefit from them. These may be 'policy entrepreneurs' who want to bring a new idea to fruition. Or they may be 'organizational entrepreneurs' within the health system itself, who seize upon newly available resources to innovate within the shifting context. Alliances between these different types of entrepreneurs, moreover, create yet further impetus for change.

The rise of policy or organizational entrepreneurs heralds potential changes in the development of health reforms and in the governance of health systems. The entrée en scène of these new players is not anecdotal. It may represent a new approach to the role of governments and states in the steering of public health systems. Authors in the field of public administration have explored characteristics of contemporary states and governments under pressure to 'modernize', and in periods of austerity or pressures to contain costs. The notion of New Weberian State (NWS) has more recently been proposed to make sense of these transformations. NWS differs from both ideas associated with NPM and with network governance: NWS is not about radical changes to the fundamental roles of government or to policies, but about incremental changes to governments facing new contingencies. As a model for public governance, NWS was initially defined by two authors ${ }^{(124)}$ as they attempted to compare the specificity of reforms in continental European countries to reforms driven by more neo-liberal states (New Zealand and Australia for example).

NWS is a response to the pressures of NPM ideas and to the idea that all public administrations should implement similar policies and use identical policy instruments to transform and adapt governments. NSW recognizes that culture (national culture for example) and institutional context ${ }^{(125)}$ are crucial dimensions that must be taken into account in the process of reform. For example, the institutional landscape associated with Canadian federalism means that it is more difficult to develop and support innovative health policies in Canada due to a strong devolution of health responsibilities to the provinces. The NWS model is coherent with recent developments around a more decentred approach to governance ${ }^{(57)}$, where the specificities of jurisdictions are recognized as crucial in the development of governance capacities ${ }^{(126)}$. Consequently, because of the attention paid to institutional embeddedness, NSW as a model of governance is more in line with an incremental and continuous approach to policy change than with bigbang reforms. This model consists in a reaffirmation of the political power of modern states as an ingredient of social cohesion and limited form of egalitarianism, but recognizes the need to develop more responsive public delivery systems and, implicitly, to incorporate a more pluralistic approach to policy making.

The authors ${ }^{(127)}$ provide a summary of the principles and approaches to governance embedded within the NWS. The New elements of NWS consist in a shift from conformity to the internal rules of bureaucracy, toward a more externally oriented and responsive public administration that focuses on citizens wishes and preferences, the supplementation of representative democracy by public consultation and participation, the implementation of results-based management and accountability, and the professionalization of bureaucrats, including the development of experts in substantive policy areas. These principles at the heart of the NWS mean that the modernization of governments will be somewhat synonymous to the emergence of big government well equipped to face contemporary challenges and collective problems.

Governing and reforming health systems become possible through growing government capacity to internalize complexity in policy making. Governments are considered the most legitimate entity to orchestrate the design of solutions at sufficient scale to address wicked problems such as achieving the Triple Aim in health care. There is recognition that only states and governments can intervene effectively in the political economy that drives health systems, to address predominant patterns of interests and the allocation of resources. Reforms are conducted by public authorities. Public authorities have the responsibility to create the conditions and spaces for innovation in the system that will promote adaptation and renewal of models of care and practices, including interventions to support the health of the population ${ }^{(127)}$.

Approaches that recall NWS with its emphasis on the role of central government in innovative policies have been used in several provinces to overcome persistent difficulties. In BC, improvements to primary care involved first creating a partnership between government and physicians to take on leadership of improvement efforts. Policies to incentivize particular activities were matched by training opportunities to increase front-line capacities to reorient practice toward priority areas, and by the creation of regional Divisions of Family Practice as forums in which physicians could learn from each other and exchange ideas for improvement ${ }^{(128,129)}$. 
In Saskatchewan, Lean methodology was promoted by government to improve quality and efficiency, notably in hospital settings, with funding for coaching and a requirement to report regularly on performance. In Ontario, government preoccupation with high service users was addressed not through a formal top-down program, but rather by encouraging voluntary partnerships among hospital and community-based providers to coordinate care for complex patients ${ }^{(130)}$. The Ontario Medical Association is supporting these efforts by offering training in establishing better connections. Each of these instances displays a new understanding that lasting and significant change requires motivating actors, investing in needed supports, time to create new relationships, and tolerance for differences in implementation. Bottom-up experimentation with new practices appears to quite naturally lead to the emergence of network efforts supported by a policy determination within central governments to support alternative practices. It will be interesting to see how, over time, these initiatives contribute to large-scale and sustainable changes.

\section{REFERENCES}

1. Lazar H, Forest PG, Church J, Lavis JN, editors. Paradigm freeze: why it is so hard to reform health care in Canada. Toronto: McGill-Queen's Press-MQUP; 2013.

2. Canadian Institute for Health Information. How Canada compares internationally: a health spending perspective, 2017: International Chartbook [Internet]. 2017; [2018 Jan 12]. Disponível em: https://www.cihi.ca/en/canadashealth-system-international-comparisons

3. Noreau P, Laborier P, Rocher G, Rioux M. Les réformes en santé et en justice. Le droit et la gouvernance. Québec: Les Presses de l'Université Laval; 2008.

4. Pollitt C, Bouckaert G. Continuity and change in public policy and management. Cheltenham: Edward Elgar Publishing; 2011.

5. Jenkins JC, Brents BG. Social protest, hegemonic competition, and social reform: a political struggle interpretation of the origins of the American welfare state. Am Sociol Rev. 1989;1:891-909.

6. Davies PS, Favreault MM. Interactions between social security reform and the supplemental security income program for the aged. Washington: The Urban Institute; 2003.

7. Howlett M. Governance modes, policy regimes and operational plans: A multi-level nested model of policy instrument choice and policy design. Policy Sciences. 2009;42(1):73-89.

8. Canadian Institute for Health Information. Physicians in Canada, 2016 [Internet]. 2017 [cited 2018 Jan 12]. Available from: https://www.cihi.ca/sites/default/files/document/physicians_in_canada_phys2016_en.pdf

9. Maynard A. Health care rationing: doing it better in public and private health care systems. J Health Polit Policy Law. 2013;38(6):1103-27.

10. Lewis S. A System in name only--access, variation, and reform in Canada's provinces. N Engl J Med. 2015;372(6):497500.

11. Health Council of Canada. Fixing the foundation: an update on primary health care and home care renewal in Canada. Toronto: Health Council; 2008.

12. Health Council of Canada. Progress timeline 2003 - 2013: highlights of health care reform [Internet]. 2014 [cited 2018 Jan 12]. Available from: https://healthcouncilcanada.ca/files/HCC_Progress_Report_Eng.pdf

13. Schoen C, Osborn R. The commonwealth fund 2010 international health policy survey in eleven countries. London: Commonwealth Fund; 2010.

14. Nasmith L, Ballem P, Baxter R, Bergman H, Colin-Thomé D, Herbert C; et al. Transforming care for Canadians with chronic health conditions: put people first, expect the best, manage for results. Ottawa (ON): Canadian Academy of Health Sciences; 2010.

15. Denis JL, Davies HT, Ferlie E, Fitzgerald L, McManus A. Assessing initiatives to transform healthcare systems: lessons for the Canadian healthcare system. Ottawa: Canadian Health Services Research Foundation; 2011.

16. Pierre-Gerlier F, Martin D. 'Fit for Purpose: findings and recommendations of the external review of the PanCanadian Health Organizations'. Ottawa: Health Canada; 2018. 
17. Saltman RB, Cahn Z. The financial crisis means that Europe will need to look beyond the public sector to provide its healthcare needs. LSE European Politics and Policy (EUROPP); 2013.

18. Coiera E. Why system inertia makes health reform so difficult. BMJ. 2011;342:d3693.

19. Sinclair DG, Rochon M, Leatt P. Riding the third rail: the story of Ontario's Health Services Restructuring Commission, 1996-2000 [Internet]. 2005 [cited 2018 Jan 15]. Available from: http://irpp.org/research-studies/ riding-the-third-rail/

20. Saltman RB, Duran A. Governance, government, and the search for new provider models. Int J Health Policy Manag. 2016;5(1):33-42.

21. Durán A, Saltman RB. Governing public hospitals. In: Kuhlmann E, Blank RB, Bourgeault IL, Wendt C, editors. The Palgrave International Handbook of Healthcare Policy and Governance. London: Palgrave Macmillan; 2015. pp. 443-61.

22. Denis JL, Usher S. Governance must dive into organizations to make a real difference: comment on "Governance, government, and the search for new provider models". Int J Health Policy Manag. 2017;6(1):49-51.

23. Saskatchewan Ministry of Health. Backgrounder: Health Region transformation across Canada [Internet]. 2017; [cited 2018 Jan 10]. Available from: https://www.saskatchewan.ca/ /media/news\%20release\%20backgrounders/2017/ jan/backgrounder\%20-\%20health\%20system\%20transformation\%20across\%20canada.pdf

24. Lewis S, Kouri D. Regionalization: making sense of the Canadian experience. Healthc Pap. 2004;5(1):12-31.

25. Hurley J. Regionalization and the allocation of healthcare resources to meet population health needs. Healthcare Papers. 2004;5(1):34-9.

26. Denis JL, Contandriopoulos D, Beaulieu MD. Regionalization in Canada: a promising heritage to build on. Healthcare Papers. 2004;5(1):40-5.

27. Osborne SP, editors. The new public governance: emerging perspectives on the theory and practice of public governance. London: Routledge; 2010.

28. Noseworthy T, Wasylak T, O'Neill B. Strategic clinical networks in Alberta: Structures, processes, and early outcomes. Healthc Manag Forum. 2015;28(6):262-4.

29. Brault I, Denis JL, Sullivan TJ. Using clinical governance levers to support change in a cancer care reform. J Health Organ Manag. 2015;29(4):482-97.

30. Batalden M, Batalden P, Margolis P, Seid M, Armstrong G, Opipari-Arrigan L; et al. Coproduction of healthcare service. Qual Saf Health Care. 2016;25:509-17.

31. Bohmer R. The Instrumental value of medical leadership. London: White Paper - The King's Fund; 2012.

32. Nelson EC, Batalden PB, Huber TP, Mohr JJ, Godfrey MM, Headrick LA; et al. Microsystems in health care: Part 1. Learning from high-performing front-line clinical units. Jt Comm J Qual Patient Saf. 2002;28(9):472-93.

33. Baker GR, MacIntosh-Murray A, Porcellato C, Dionne L, Stelmacovich K, Born K. High performing healthcare systems: delivering quality by design. Toronto: Longwoods Publishing; 2008.

34. Chattergoon S, Darling S, Devitt R, Klassen W. Creating and sustaining value: building a culture of continuous improvement. Health Manag Forum. 2014;27(1):5-9.

35. The Health Foundation. Using clinical communities to improve quality [Internet]. 2013; [cited 2016 March 18]. Available from: https://www.health.org.uk/publications/using-clinical-communities-to-improve-quality

36. Langley A, Denis JL. Beyond evidence: the micropolitics of improvement. Qual Saf Health Care. 2011;20(Suppl 1):i43-6.

37. Verma JY, Denis JL, Samis S, Champagne F, O'Neil M. A Collaborative approach to a chronic care problem. Health Pap. 2016;15:19-38.

38. Alberta Health Services. Strategic Clinical Networks: A primer and working document [Internet]. 2012; [cited 2018 Jan 13]. Available from: https://www.albertahealthservices.ca/assets/about/scn/ahs-scn-primer.pdf

39. Dyck D. Strategic clinical networks in Alberta. Montreal: Conference of the MUHC-ISAI; 2017. 
40. Marchildon G. Implementing Lean health reforms in Saskatchewan. Health Reform Observer - Observatoire des Réformes de Santé. 2013;1(1).

41. Adler PS, Borys B. Two types of bureaucracy: enabling and coercive. Adm Sci Q. 1996;41:61-89.

42. Ferlie E, Gerry Mcgivern, FitzGerald L. A New mode of organizing in health care? governmentality and managed networks in cancer services in England. Soc Sci Med. 2012;74(3):340-7.

43. Denis JL, Baker R. Medical doctors and health system improvement: synthesis results and propositions for further research. In: Kuhlmann E, Blank RB, Bourgeault IL, Wendt C, editors. The Palgrave International Handbook of Healthcare Policy and Governance. London: Palgrave Macmillan; 2015. pp. 88-103.

44. Denis JL, Baker GR, Black C, Langley A, Lawless B, Le Blanc D; et al. Exploring the dynamics of physician engagement and leadership for Health System Improvement: prospects for Canadian Healthcare Systems [Internet]. 2013; [cited 2016 Mar 18]. Available from: http://www.getoss.enap.ca/GETOSS/Publications/Lists/ Publications/Attachments/438/Expedited_Synthesis_CIHR_2013-04-10-Final.pdf

45. Baker GR, Denis JL. Medical leadership in health care systems: from professional authority to organizational leadership. Publ Money Manag. 2011;31(5):355-62.

46. Dickens P, Fisman S, Grossman K. Evaluation of the Physician leadership development program at Schulich. Canadian Journal of Physician Leadership. 2016;2(3).

47. Specialist Services Committee. British Columbia. Physician quality improvement initiative [Internet]. 2018; [cited 2018 Feb 02]. Available from: http://www.sscbc.ca/physician-engagement/regional-quality-improvement-initiative

48. Hutchison B, Glazier R. Ontario's primary care reforms have transformed the local care landscape, but a plan is needed for ongoing improvement. Health Aff. 2013;32(4):695-703.

49. Marchildon GP, Hutchison B. Primary care in Ontario, Canada: new proposals after 15 years of reform. Health Policy. 2016;120(7):732-8.

50. Wranik D, Katz A. A Typology of pay-for-performance programs in publicly funded primary healthcare systems. Health Syst Policy Res. 2015;2(1):6.

51. Hutchison B, Lévesque JF, Strumpf E, Coyle N. Primary health care in Canada: systems in motion. Milbank Q. 2011;89(2):256-88.

52. Denis JL, van Gestel N. Medical doctors in healthcare leadership: theoretical and practical challenges. BMC Health Serv Res. 2016;16(Suppl 2):158.

53. Canadian Nurses Association. Nurse Practitioners: untapped resource [Internet]. 2017; [cited 2018 Feb 03]. Available from: https://cna-aiic.ca/-/media/cna/page-content/pdf-en/nurse-practitioners_untapped-resource.pdf

54. Canadian Pharmacists Association. Scope of practice [Internet]. 2015; [cited 2018 Feb 02]. Available from: http:// napra.ca/sites/default/files/documents/Scope_of_Practice_Pharmacists_Dec2015.pdf

55. Canadian Association of Physician Assistants. National report card [Internet]. 2017; [cited 2018 Jan 09]. Available from: https://capa-acam.ca/2017/11/physician-assistant-implementation-2017-national-report-card/

56. Pollitt C, Bouckaert G. Public management reform. A comparative analysis - Into The Age of Austerity. Oxford: Oxford University Press; 2017.

57. Bevir M, Waring J, editors. Decentring health policy: learning from British experiences in healthcare governance. London: Routledge; 2017.

58. Townley B, Cooper DJ, Oakes L. Performance measures and the rationalization of organizations. Organ studies. 2003;24(7):1045-71.

59. Aucoin P. New political governance in Westminster systems: impartial public administration and management performance at risk. Governance. 2012;25(2):177-99.

60. Bryson JM, Crosby BC, Bloomberg L. Public value governance: moving beyond traditional public administration and the new public management. Pub Adm Rev. 2014;74(4):445-56.

61. Hood C. A public management for all seasons? Public Adm. 1991;69(1):3-19.

62. Osborne D, Gaebler T. Reinventing Government. New York: Taylor Francis; 1992. 
63. Rhodes RAW. Understanding governance: policy networks, governance, reflexivity and accountability. England: Open University Press; 1997.

64. Forest PG, Denis JL, Brown LD, Helms D. Health Reform Requires Policy Capacity. Int J Health Policy Manag. 2015;4(5):265-66.

65. Denhardt JV, Denhardt RB. The new public service: serving, not steering. London: Routledge; 2015.

66. Breton M, Lévesque JF, Pineault R, Lamothe L, Denis JL. Integrating public health into local healthcare governance in Quebec: challenges in combining population and organization perspectives. Healthc Policy. 2009;4(3):e15978.

67. Ansell C, Gash A. Collaborative governance in theory and practice. J Public Adm Res Theory. 2008;18(4):54371.

68. Best A, Greenhalgh T, Lewis S, Saul JE, Carroll S, Bitz J. Large $\square$ system transformation in health care: a realist review. Milbank Quarterly. 2012;90(3):421-56.

69. Wang J, Jacobs P, Ohinmaa A, Dezetter A, Lesage A. Public expenditures for mental health services in Canadian provinces: dépenses publiques pour les services de santé mentale dans les provinces canadiennes. Can J Psychiatry. 2018;63(4):250-6.

70. Canadian Home Care Association. Better home care in Canada: a national action plan [Internet]. 2016; [cited 2017 Nov 18]. Available from: Accessed at: http://www.thehomecareplan.ca/wp-content/uploads/2016/10/BetterHome-Care-Report-Oct-web.pdf

71. Denis JL, Forest PG. Real reform begins within: an organizational approach to health care reform. J Health Polit Policy Law. 2012;37(4):633-45.

72. Alford R. Health care politics. Chicago: University of Chicago Press; 1975.

73. Pierson P. Increasing returns, path dependence, and the study of politics. Am Polit Sci Rev. 2000;94(2):251-67.

74. Naylor D, Francine G, Mintz JM, Fraser N, Jenkins T, Power C; et al. Unleashing innovation: excellent healthcare for Canada : report of the advisory panel on healthcare innovation [Internet]. 2015; [cited 2017 Nov 18]. Available from: Accessed at: http://www.deslibris.ca/ID/247266.

75. Fitzgerald L, McDermott A. Challenging perspectives on organizational change in health care. New York: Taylor \& Francis; 2017.

76. Herzlinger RE. Why Innovation in Health Care Is so Hard. Harvard Bus Rev. 2006;84(5):58.

77. Paina $\mathrm{L}$, Peters $\mathrm{DH}$. Understanding pathways for scaling up health services through the lens of complex adaptive systems. Health Policy Plan. 2012;27(5):365-73.

78. Atun R. Health systems, systems thinking and innovation. Health Policy Plan. 2012;27(suppl 4):iv4-8.

79. Dougherty D. Bridging social constraint and social action to design organizations for innovation. Organ Stud. 2008;29(3):415-34.

80. Buchanan DA, Fitzgerald L, Ketley D. The sustainability and spread of organizational change: modernizing healthcare. London: Routledge; 2006.

81. Greenhalgh T, Robert G, Macfarlane F, Bate P, Kyriakidou O. Diffusion of innovations in service organizations: systematic review and recommendations. Milbank Q. 2004;82(4):581-629.

82. Greenhalgh T, Wherton J, Papoutsi C, Lynch J, Hughes G, A'Court C; et al. Beyond adoption: a new framework for theorizing and evaluating nonadoption, abandonment, and challenges to the scale-up, spread, and sustainability of health and care technologies. J Med Internet Res. 2017; 19(11):e367.

83. Shaw J, Shaw S, Wherton J, Hughes G, Greenhalgh T. Studying scale-up and spread as social practice: theoretical introduction and empirical case study. J Med Internet Res. 2017;19(7):e244.

84. Van de Ven AH, Polley D, Garud R, Venkataraman S. The Innovation Journey. Oxford: Oxford University Press; 1999.

85. Kyratsis $Y$, Ahmad R, Holmes A. Making sense of evidence in management decisions: the role of research-based knowledge on innovation adoption and implementation in healthcare. Study protocol. Implement Sci. 2012;7:22. 
86. Rogers EM. Diffusion of Innovations. New York: MacMillan Publishing Co; 1995.

87. Edler J. Demand oriented innovation policy. The Theory and practice of innovation policy an international research handbook. Cheltenham: Edward Elgar; 2010.

88. Thakur R, Hsu SHY, Fontenot G. Innovation in healthcare: issues and future trends. J Bus Res. 2012;65(4): 562-9.

89. Denis JL, Langley A, Sergi V. Leadership in the Plural. Acad Manag Annals. 2012;6(1):211-83.

90. Slaghuis SS, Strating MMH, Bal RA, Nieboer AP. A Framework and a measurement instrument for sustainability of work practices in long-term care. BMC Health Serv Res. 2011;11(1):314.

91. Bekkers VJJM, Edelenbos J, Nederhand J, Steijn AJ, Tummers LG, Voorberg WH. The Social Innovation Perspective in the Public Sector: Co-Creation, Self-Organization and Meta-Governance. New York: Palgrave Macmillan; 2014.

92. Vries H, Bekkers V, Tummers L. Innovation in the Public Sector: A Systematic review and future research agenda. Public Adm. 2016;94(1):146-66.

93. Milat AJ, Bauman A, Redman S. Narrative review of models and success factors for scaling up public health interventions. Implement Sci. 2015;10:113.

94. Knorr Cetina K. Les épistémès de la société: l'enclavement du savoir dans les structures sociales. Sociol Soc. 1998;30(1):39-54.

95. Feldman MS, Orlikowski WJ. Theorizing practice and practicing theory. Organ Sci. 2011;22(5):1240-53.

96. Dougherty D. Organizing practices in services: capturing practice-based knowledge for innovation. Strateg Organ. 2004;2(1):35-64.

97. Gibbons M, Limoges C, Nowotny H, Schwartzman S, Scott P, Trow M. The new production of knowledge: the dynamics of science and research in contemporary societies. Newbury Park: Sage Publishing; 1994.

98. Weick KE. Sensemaking in organizations. Newbury Park: Sage Publishing; 1995.

99. Callon M, Lascoumes P, Barthe Y. Agir dans un monde incertain. Essai sur la démocratie technique. Paris: Le Seuil; 2001.

100. Nowotny H, Scott P, Gibbons M. Re-thinking science: Knowledge and the public in an age of uncertainty. Cambridge: Polity; 2001.

101. Cohen WM, Levinthal DA. Absorptive capacity: a new perspective on learning and innovation [Internet]. 2016; [cited 2017 Nov 18]. Available from:https://pdfs.semanticscholar.org/e13a/7fa97fc66457dcf525608ea64f26a11 8efa3.pdf

102.Lane PJ, Lubatkin M. Relative absorptive capacity and interorganizational learning. Strat Mgmt J. 1998;19(5): 461-77.

103.Zahra SA, George G. Absorptive capacity: a review, reconceptualization, and extension. Acad Manage Rev. 2002;27(2):185-203.

104.Alvesson M. Organizations as rhetoric: knowledge-intensive firms and the struggle with ambiguity. J Manag Stud. 1993;30(6):997-1015.

105. Alvesson M. Knowledge work: ambiguity, image and identity. Hum relat. 2001;54(7):863-86.

106. Friedland R, Alford RR. Bringing society back in: symbols, practices and institutional contradictions. Chicago: University of Chicago Press; 1991.

107. Clemens ES, Cook JM. Politics and institutionalism: explaining durability and change. Annu Rev Sociol. 1999;25(1), 441-66.

108. Garud R, Hardy C, Maguire S. Institutional entrepreneurship as embedded agency: an introduction to the special issue. Organ Stud. 2007;28(7):957-69.

109. Greenwood R, Suddaby R. Institutional entrepreneurship in mature fields: the big five accounting firms. Acad Manage J. 2006;49(1):27-48. 
110. Lockett A, Currie G, Waring J, Finn R, Martin G. The role of institutional entrepreneurs in reforming healthcare. Soc Sci Med. 2012;74(3):356-63.

111. Zietsma C, Lawrence TB. Institutional work in the transformation of an organizational field: the interplay of boundary work and practice work. Adm Sci Q. 2010;55(2):189-221.

112. Grenier C, Denis JL. S'organiser pour innover: espaces d'innovation et transformation des organisations et du champ de l'intervention publique. Rev Politiq Manage Public. 2017;34(3-4):191-206.

113. Lehoux P, Miller FA, Daudelin G. How does venture capital operate in medical innovation? BMJ Innovations. 2016;2(3):111-7.

114. Clayton MC, Raynor ME, McDonald R. What is disruptive innovation. In: Interaction Design Fundation. The Encyclopedia of Human-Computer Interaction [Internet]. 2016; [cited 2017 Dec 18]. Available from: https://www. interaction-design.org/literature/book/the-encyclopedia-of-human-computer-interaction-2nd-ed

115. Clayton MC, Bohmer R, Kenagy J. Will disruptive innovations cure health care? Harv Business Rev. 2000;78(5): 102-12.

116. Clayton MC, Overdorf M. Meeting the challenge of disruptive change. Harv Business Rev. 2000;78(2):66-77.

117. Hwang J, Clayton MC. Disruptive innovation in health care delivery: a framework for business-model innovation. Health Aff. 2008;27(5):1329-35.

118. Coombs R, Metcalfe JS. Organizing for Innovation: co-ordinating distributed innovation capabilities. In: Foss N, Mahnke V. Competence, governance, and entrepreneurship. Advances in economic strategies research. Oxford: Oxford University Press; 2002

119. Moore M, Hartley J. Innovations in Governance. Public Manage Rev. 2008;10(1):3-20.

120. Hartley J. Innovation in governance and public services: past and present. Public Mon Manage. 2005;25(1): 27-34.

121.Friedman CP, Allee NJ, Delaney BC, Flynn AJ, Silverstein JC, Sullivan K; et al. The Science of learning health systems: foundations for a new journal. Learn Health Syst. 2017;1(1).

122. Fitzgerald L, Ferlie E, Wood M, Hawkins C. Interlocking interactions, the diffusion of innovations in health care. Hum Relat. 2002;55(12):1429-49.

123. Tuohy $\mathrm{CH}$. Reform and the politics of hybridization in mature health care states. J Health Polit Policy Law. 2012;37:611-32.

124.Pollitt C, Bouckaert G. Public management reform: a comparative analysis. New York: Oxford University Press; 2004.

125.Pierson P. The limits of design: explaining institutional origins and change. Governance. 2000;13(4):475-99.

126. Christens BD. Vehicles of change: context and participation in power-based community organizing [thesis]. Nashville: Vanderbilt University; 2008.

127.Pollitt C, Bouckaert G. Continuity and change in public policy and management. Cheltenham: Edward Elgar Publishing; 2011.

128. MacCarthy D, Kallstrom L, Kadlec H, Hollander M. Improving primary care in British Columbia, Canada: evaluation of a peer-to-peer continuing education program for family physicians. BMC Med Educ. 2012;12:110.

129. Cavers WJ, Tregillus VH, Micco A, Hollander MJ. Transforming family practice in British Columbia: The General Practice Services Committee. Can Fam Physician. 2010;56(12):1318-21.

130. Closson T. The Goldilocks principle and Canadian healthcare system governance [Internet]. 2014; [cited 2017 Dec 14]. Available from: https://healthydebate.ca/opinions/the-goldilocks-principle-and-canadian-healthcaresystem-governance

\section{Mailing address:}

Jean-Louis Denis

Department of Management, Evaluation and Health Policy - School of Public Health, Universite de Montréal

7101 Park Ave, QC H3N 1X9

Montréal - Canada

E-mail: jean-louis.denis@umontreal.ca 